\title{
Return Imaginaries and Political Climate: Comparing Thinking About Return Mobilities Among Pakistani Origin Migrants and Descendants in Norway and the UK
}

\author{
Marta Bolognani $^{1} \cdot$ Marta Bivand Erdal $^{2}$
}

Published online: 12 February 2016

(C) The Author(s) 2016. This article is published with open access at Springerlink.com

\begin{abstract}
The political climate on immigration and diversity in various European societies has previously been analysed in relation to media representations, policy regimes and public opinion. This paper focuses more narrowly on how political climates affect migrant and post-migrant generations, as inhabitants of these European societies. We focus on the impact of ambivalence resulting from perceived lack of recognition as full citizens in European societies among migrants and their descendants. Ambivalence in relation to experiences of particular traits of the political climate is further connected with ideas about mobility-how migrants and descendants may think about return migration - what we discuss in terms of 'return imaginaries'. Culture, ideology and representations are seen as significant for contemporary politics, not only with expressive but also with formative roles. With this perspective, the analysis explores three politically heated areas of debate: about immigration control, about social cohesion and integration agendas and about terrorist attacks. These three areas were inductively selected, drawing on analysis of qualitative data collected among Pakistani origin migrants and descendants in Norway and the UK. The two countries of residence are purposefully chosen because they in different ways reflect political climates affected by the rise of xenophobia and Islamophobia in Europe.
\end{abstract}

Keywords Return $\cdot$ Migration $\cdot$ Imaginary $\cdot$ Politics $\cdot$ Integration $\cdot$ Islamophobia

Marta Bivand Erdal

marta@prio.org

Marta Bolognani

m.bolognani@bristol.ac.uk

1 University of Bristol, Bristol, UK

2 Peace Research Institute Oslo, Oslo, Norway 


\section{Introduction}

Concerns over social cohesion and integration of migrants and descendants of migrants are at the centre of heated political debates about the future of European societies, as reflected in the rise of right-wing populist political parties across Europe since the late 2000s (Y1lmaz 2012). This increase in xenophobia and Islamophobia in Europe is closely connected to debates about immigration — and in some cases diversity - being seen as a threat to economic and cultural sustainability of Western societies. The role of political rhetoric and media representations in framing immigration and diversity debates is critical for the development of public perceptions. We refer to the sum of the interactions of political rhetoric, media representations and resulting public perceptions as formative traits of political climate. In this article, we seek to explore the ways in which such 'political climates' are experienced by migrants and descendants of Pakistani origin in Norway and the UK, specifically in relation to 'return imaginaries'.

Numerous studies explore the roles of media coverage in relation to public opinions about immigration (see, e.g. Blinder and Jeannet 2014, Figenschou and Beyer 2014a, 2014b, McKay et al 2011), or the connections between different policy regimes and public perceptions of immigration (see, e.g. Blinder, 2013, Fangen and Vaage 2014, Ford et al 2015). An emergent body of work explores the ways in which particular political climates vis á vis immigration and diversity also impact on migrant or minority populations themselves, as explored in the case of Latino politics in the US by Pérez (2015). This article seeks to contribute to this emergent field of studies, focusing on migrants' own experiences of particular traits of political climate pertaining to immigration and diversity.

For migrants and their descendants, we argue, changing political climates pertaining to questions about immigration and diversity may matter in different ways. Migrants and their descendants often juggle attachments to people and places located across transnational social fields as 'balancing acts' (Erdal and Oeppen 2013). While some migrants engage actively in such juggling, perhaps with a sense of ambivalence (Erdal 2014), others may feel multiple ties as a resource, or indeed feel attachment in neither place and thus feel generally alienated (Carling and Pettersen 2014). The multiplicity of experience here should not be overlooked, and it is reasonable to assume that it is also intertwined with the political climate of any given period of time. For different migrant generationsdepending on the arrival period, as well as age at arrival, and life course stage - different political climates may affect both settlement experiences and return imaginaries in contrasting ways, where the distinctiveness of migrant experiences and those of subsequent generations need to be acknowledged (Erdal and Ezzati 2015; Eriksen 2015).

While there is ambivalence with regard to the juggling of multiple attachments which can be rooted in the self - and its own journey and process of identity constructionwe choose here to focus on ambivalence which is connected with particular political climates, especially rooted in a perceived lack of recognition as full citizens in European societies. The fact that minority populations are at the receiving end of discrimination or racism is well documented, as is the fact that this has an impact on their lives in countries of immigration. Our aim in this article is to further develop the understanding of how particular political climates - at a societal level — affect not only lives in the country of immigration as such, but also lives which are often transnationally anchored, through a connection between political climates and the return imaginaries of migrants and sometimes also of their descendants. 
We draw on qualitative data collected among Pakistani migrants and their descendants living in the UK and Norway. We limit ourselves to their experiences of particular traits of political climate: political rhetoric, media representations and resulting public perceptions. At the same time, we acknowledge that for most the everyday lived experiences of recognition — or lack thereof — in encounters and interactions with neighbours, colleagues, shop keepers, medical staff or children's teachers are likely to be of greater significance, than the more distanced political climate. Nevertheless, the analysis of our qualitative data points to the relevance of the scale of 'the political climate', and more specifically to a link between perceptions of the political climate and changing return imaginaries. Thus, the focus of this article is on the interplay of perceptions of particular traits of political climate in Norway and in the UK with migrants' and descendants' return imaginaries and draws heavily on a bottom-up reading and analysis of our data.

By 'return imaginaries', we refer to the ways in which migrants and descendants may consciously and unconsciously at some level consider the possibility of 'return mobilities', whether at a hypothetical or more realistic level (Bolognani 2015). While return migration preconditions a country of origin once left to which one can return, it is common to also include migrants' descendants in studies of return, discussed as 'ethnic return', 'ancestral return', 'second-generation return' or 'counter-diasporic return' (see, e.g. King and Christou 2014). Following insights from studies of such 'return', we acknowledge that many (though not all) children of migrants are influenced by their parents' migration history, and for some, connections to an ancestral homeland remain salient, at an emotional or symbolic level, although for most practical purposes their lives may be firmly anchored in their parents' country of immigration.

Theoretically, return imaginaries should be seen as part of an analytical effort drawing inspiration from the mobilities' turn in the social sciences (see, e.g. Hannam et al 2006). As part of the mobilities' turn, there is an increase in interest in migration as well as everyday small-scale mobility. However, there still seems to be need for further work on the impact of ideas about mobility in a broader sense, including seeing mobilities of different kinds as discursive realities (Carling 2002). Some emerging work which deals with impacts of the idea of mobility (or immobility) focuses on migration aspirations, for instance among young girls in Ghana and Côte d'Ivoire (Thorsen 2010), where the idea of mobility is closely connected with ideas about better economic opportunities. Other studies focus on ideas about non-moving and sedentarism, for instance in a Swedish urban context (Hjälm 2014), discussing the ways in which ideas about mobility and sedentarism to different extents shape people's actions. In the context of research on return migration, the idea of mobility is central, as reflected in the much cited phrase 'the myth of return', but the emphasis in much of the research has been on the actual mobility that takes place, rather than the implications of the imaginary of 'the myth of return', beyond 'return migration' itself (Bolognani 2015, Carling 2015).

Recent exceptions include work by Carling and Pettersen (2014) whose analysis of survey data on migrants' return intentions and how they interact with their transnational ties acknowledges that return intentions in themselves are significant ideas about mobility worth exploring even when they do not translate into actual mobility. Bolognani (2015) illustrates how return fantasies are not necessarily a symptom of disengagement with society but rather have the potential to create a transitional space where the individual can re-elaborate experiences in a mode that is safer than the one of reality and which may have a positive effect on actual processes of settlement 
throughout the migration experience. This article contributes to the exploration of ideas about mobility and their discursive and imaginary impact by focusing on the ambivalence generated by a perceived lack of recognition among some migrants and descendants in terms of being seen as full citizens in European societies.

While there are striking similarities in some regard between the Pakistani migrant populations in the UK and Norway, as also in comparison with similar communities in Denmark (see, e.g. Rytter 2011), there are some differences which make a combined analysis of the two cases particularly relevant. One main difference pertains to the migration history. In the UK, there is a longer history of Pakistani migration, greater numbers and a former colonial history; by contrast, in Norway, despite more than four decades of immigration from Pakistan, these migration flows are still perceived as relatively recent in the public eye. The length of stay of many Pakistani families in Norway, however, means that grandchildren are being born and going to school, signalling that the migration history is perhaps more established than commonly acknowledged.

The political context of relevance to the analysis of this article in each of the two countries is affected by their particular histories, politically as well as with regard to immigration. Despite some key differences, there are also some trends which seem to be fairly consistent, Europe-wide, such as the increase in popular support for right-wing political parties or movements (Y1lmaz 2012). The extent of this increase is open to debate, but the results from European Parliament elections in 2014, with high levels of support among other for UKIP, may serve as an indicator. Although the sweeping results of UK Independence Party (UKIP) are in a way very recent (although it is arguable whether they could have been predicted), and in spite of a strategic and systematic recruitment of minority ethnic representatives, there is wide consensus that their success is based mainly on their anti-immigration campaigns (Martin \& Smith 2014). It has also been argued that UKIP's sentiments have influenced both Labour ${ }^{1}$ and the Conservatives, ${ }^{2}$ just as in the rest of Western Europe, the right-wing populist's agenda seems to have pushed the mainstream political parties towards converging positions (Pardos-Prado et al 2013). Some debates on immigration also take into account specific Islamophobic positions, pushing a representation of Muslims as fifth columnists (Spalek 2011). This draws on previous anxieties related to civil unrest in large Muslim communities, e.g. in the north of England, creating a complex media discourse that binds immigration, terrorism and integration into one. Parallel conflation of connected but distinct themes also occur in Norwegian mediatised debates, political rhetoric and public perceptions, all making up what we refer to as the political climate (see, e.g. Figenschou and Beyer 2014ab, Fangen and Vaage 2014).

\section{Expressive and Formative Political Stances Influencing Return Imaginaries}

This article draws on comparative analysis of the British and Norwegian contexts, focusing on three areas where heated debate related to questions of immigration and

\footnotetext{
${ }^{1}$ Shilton, J. (2014) Labour embraces UK Independence Party's right wing nationalism. Available at http://www. wsws.org/en/articles/2014/06/07/ukip-j07.html

${ }^{2}$ Hasan, M. (2014) The rise of Ukip spells defeat for Cameron's Conservatives. Available at http://www. huffingtonpost.co.uk/mehdi-hasan/ukip-david-camerons-worse_b_5390346.html
} 
diversity shapes political climates and in turn affects Pakistani migrants' and their descendants' return imaginaries: first, immigration control; second, social cohesion and integration agendas; and third, terrorist attacks, as critical events, which spur politicisation of immigration and diversity debates.

We argue that the focus of political debates, whether on immigration control or on social cohesion and integration, has unavoidably been introjected by the general public, including, of course, populations of Pakistani origin themselves. We bring to the fore the dynamics at work behind such representations in order to understand their historical constraints. We believe that by doing so, the understanding of their effects on migrants and their descendants will be enhanced. We thus start from the theoretical assumption that everyday or popular culture representations, as Stuart Hall famously put it:

do play a constitutive, and not merely a reflexive, after-the-event, role. This gives questions of culture and ideology, and the scenarios of representation-subjectivity, identity, politics - a formative, not merely an expressive, place in the constitution of social and political life. (Hall, 1996, p. 443)

In other words, political debates, whether on immigration control, on social cohesion and integration, or on terrorism, are a reflection of how ideologies or policies hegemonically influence everyday life but may also provide some insights as to how 'subjectivity, identity and politics' may be changed through practice, in particular in the case of 'return imaginaries' as they are articulated in the minds of migrants and their descendants.

In our longstanding research engagement with Pakistani migrants and descendants in the UK and Norway (Bolognani 2007, 2014, 2015; Erdal 2012, 2013; Erdal et al. 2015), we find that a great majority of research participants bring up issues related to the prevalent political climate, regardless of whether or not this is connected with the research question informing the interview. So for instance, in research projects focusing explicitly on transnational ties, such as sending remittances, or on Islamic charity and development efforts, research participants raise issues related to their place in society and about the contingent nature of their belonging in the UK or Norway, regardless of formal citizenship status and of the socio-economic position.

The questions around the place of Pakistanis in European societies sketched above are ancillary to political stances on migration and integration that are defining of contemporary Europe. They are simultaneously of an expressive and of a formative nature, as argued by Stuart Hall (1996, p. 443). These themes do not only represent a certain spirit of the time, a hegemonic ideology (and thus expression of a historical moment), but also contribute to create a cognitive (formative) map that shapes the way social actors interpret their own personal experiences and navigate their choices. We hence argue that Pakistani migrants and their descendants are necessarily bound to relate to particular political stances (of an expressive nature) and their thoughts and priorities are affected by them in different ways (as they become formative). In this article, we go on to analyse in further detail how specific political stances may affect Pakistani migrants' and descendants in relation to shaping return imaginaries. Our multi-sited fieldwork highlighted how Pakistani migrants and their descendants were affected by expressive and formative debates on (1) immigration control (through constraints on visas and family reunification); (2) social cohesion and integration 
agendas (putting the onus on the migrants to 'integrate themselves', while the public opinion and the popular press may act in alienating ways); and (3) terrorist attacks as critical events.

For many of our research participants, Pakistan is a country they have never lived in. Yet, among British Pakistanis, who have already borne a third generation, Bolognani (2014) describes how in the midst of public questioning of their loyalty to the UK they cannot help but wonder what it would be like 'back home'. The survival of the expression 'back home', even among those British Pakistanis who have never visited Pakistan, betrays the resilience of the idea of another home, even when their hyphenated label of choice is British Muslim (Bolognani and Statham 2013). In the Norwegian context, the hyphenated identity Norwegian-Pakistani is commonly used among the ones who are born and raised in Norway. For reasons connected mainly with religion and race, and despite formal citizenship and everyday inclusion in work places and schools, in media and in politics, the label 'just Norwegian' is not something they can avail themselves of and which they wonder whether their children will be able to use in the future (Erdal 2013). While many Norwegian-Pakistanis may be content with a hyphenated identity, as reflective of their dual ties and belonging, it is striking how exclusion from Norwegianness is experienced as alienating, in particular in the long run (see also Fangen 2007a, Fangen 2007b, Vassenden 2010).

However, in both the British and Norwegian contexts, the fact that the political climate leads to a questioning of belonging does not translate into an exodus of migrants. Therefore, the hypothesis of this article is that political climate in immigration countries contributes to maintaining a discursive possibility of return open, this includes an expressive value, but their formative force is often more evident in the narration of imaginaries, than in any actual mobility. The following section sets out the methods and data used in this article. The subsequent three sections draw on our data, together with conceptual and empirical insights from other studies, in a discussion of how different aspects of the political climate in countries of settlement affect migrants' and their descendants' return imaginaries.

\section{Methods and Data}

This article draws on research within the Possibilities and Realities of Return Migration project. $^{3}$ The project focused both on migrants' considerations and thoughts about the possibility of return, while living in the UK and Norway, and on the actual experiences of return migrants post-return. In this article, we focus on the former, including Pakistani migrants and their descendants living in the UK and Norway. Our primary data includes a total of 31 semi-structured interviews and 7 focus groups, involving 63 individuals. Data collection in the UK was conducted in the period SeptemberDecember 2011, whereas in Norway in the period February-July 2012.

The research participants were recruited through a number of different entry points, including prior networks and contacts, as well as institutional or organised entry points, in order to maximise diversity. The group of research participants in each country as a whole was composed of a balanced sample of women and men, of different ages, and

\footnotetext{
${ }^{3}$ www.prio.org/premig
} 
with different socio-economic strata. Efforts were made to reach populations which often may be hard to reach, those speaking poor English or Norwegian, rather than opting for easier-to-access higher educated individuals only. The data was transcribed and coded in the qualitative software programme NVivo, following a project-wide codebook. The analysis for this paper followed an inductive approach and a back-andforth between data and the underlying conceptual questions of relationships between the political climate and migrants' and descendants' return imaginaries, regardless of whether or not actual mobility was involved.

This primary data was supplemented by insights and reflections from the researchers' engagements with Pakistani communities in the UK and Norway within multiple research projects in the past decade, contextualising the present findings and providing a point of reference for the development of this article (see e.g. Bolognani 2007, 2014; Erdal 2012, 2013).

\section{Political Climate I: Immigration Control}

While the vast majority of Pakistani migrants and descendants in the UK and Norway have regular status and a majority have citizenship (77\% among Norwegian-Pakistanis), issues related to immigration control continue to affect them as members of transnational families. There is also a proportion of Pakistanis with irregular status in the UK and in Norway, though it is hard to estimate numbers (Ahmad 2008). In our data-where we did not ask about immigration control as such — we found that immigration control was still raised by informants in relation to two sets of issues: visas for family members to visit the UK or Norway and transnational marriages between partners in the UK or Norway and in Pakistan.

At a general level, when research participants told us about plans for visits of family and relatives from Pakistan, the issue of obtaining a visa was one which was frequently brought up, and many had experiences of grandparents not being able to come to take part in important occasions with grandchildren, due to difficulties with getting a visa. While mainly an issue connected with family events and taking part in grandchildren's lives in Norway, the question of obtaining visas ultimately was also connected with how the Norwegian state via the embassy in Islamabad views the population of Pakistani descent in Norway. The theme of trust is a key part of this, where migrants in Norway experience that the Norwegian state, with regard to visas for family and relatives in Pakistan, does not trust them sufficiently. While many express an understanding of the need the authorities have for controlling immigration, they question the assessments of risk of overstaying visas for their relatives coming for visits to Norway. Rather, the visa policies were seen to hit the wrong target and have an emotional effect on children of migrants as well as on migrants themselves, as much as on the individuals not permitted to enter Norway for a visit. The fact that this aspect of Norwegian visa policies was not seen to be considered as important was mentioned, with references to the strong Norwegian traditions of family celebrations for instance in connection with confirmation of adolescents, where it would be unheard of if grandparents were not permitted to attend. The impression was that NorwegianPakistanis do not have equal rights to family celebrations of these kinds in Norway, because of the transnational nature of their families. Furthermore, visa troubles 
were a clear reminder of state's roles in upholding unequal access to mobility resources, which translate into asymmetrical relationships in transnational families (Carling 2008).

At the time of the UK fieldwork, there was some discussion over new rules to be implemented for UK citizens wanting to bring over a non-European spouse; eventually, in July 2012, a new piece of legislation made it impossible for citizens earning the minimum wage to sponsor their spouse, as they would need to earn at least $£ 18,600$. The legal and economic arguments around immigration control, however, only partially overlap with the interest in the topic by UK interviewees. Rather, the issues of equal treatment that should be embedded in an idea of belonging was what emerged as pivotal in preoccupations around the topic. A specific example will clarify the anxiety around belonging triggered by the bureaucracy around marriage migration. Iqbal, in his late thirties, came to the UK as a baby and grew up in a white area, attended a Christian school and tended to have more white friends than others. Financially settled and widely recognised for having opened a local charity dealing with underachievement, discrimination and Islamophobia, he had not thought about migrating to Pakistan. Having gotten married to a woman in Pakistan, who came to the UK to join him, his position changed. In 2009, while applying for his wife's indefinite leave to remain, the Home Office suggested she should consider returning to Pakistan, as her husband could be 'reasonably expected to live' there because of his Pakistani heritage. This personal experience of the larger political context he was already very aware of made all the difference for him personally. The idea of return to Pakistan suddenly came to surface, as he experienced that his life and work in the UK was perceived as less important in the UK than his 'Pakistani heritage'.

The implication of the political climate on immigration control, as experienced by our research participants, leads to sustaining the discursive possibility of return, mainly at the level of a troubled feeling of never quite being sure that you really belong. Among interviewees, there is a clear sense that despite holding a European citizenship, there are somehow double standards at play. The feeling that the majority population will always consider you a migrant proves formative for the discursive possibility of return both being kept alive, but also coming into play as a discursive option at all. The political climates are in this instance, not simply a reflection of political visions or ideology growing in popularity, but clearly they are also shaping the practice of the people who are the subject of those discourses, pushing them to face their ambivalences about their belonging and making sense of it. The emphasis on belonging in the discussion of immigration control issues leads to the topics of social cohesion and integration as they are experienced by our interviewees.

\section{Political Climate II: Social Cohesion and Integration}

Lived experience among research participants in both the UK and Norway was dominated by participation in different spheres of societal life, whether in education, the labour market, business, leisure, religion or other arenas. In their reflections pertaining to social cohesion or integration agendas in their respective national contexts, we found a clear similarity in the ambivalence with which many experienced public debates on these themes. This ambivalence relates to the fact that many of the Pakistani migrants and descendants we spoke to are strong defenders of core values of 
these societies, such as individual freedom and gender equality. Simultaneously, in the mediatised public opinion, they often feel cast as 'the enemy of the people' and a threat to the same core societal values. However, given the two separate national contexts, we also found differences in relation to how research participants read and reacted to the political climate on social cohesion and integration, perhaps with one clear difference being that 'British multiculturalism' was explicitly discussed and defended as a model for inclusion processes. For example, Zulfikar, a 55-year-old man who migrated to Britain when he was 12 years old, married to a white woman he met at a university and, living in a predominantly white area, argues not only that he would not return to Pakistan, but that he could not move to any other country, as he can only be at home within British multiculturalism. This is in spite of his career in the public sector which has prompted him to challenge institutional racism, expressed according to him, for instance, in the school curriculum.

In our encounters with Pakistani migrants and descendants, we found that individual freedom and gender equality were values in the Norwegian and British societies that were highly appreciated. In both contexts, we conducted focus groups with women, and in efforts to reach out to those not fluent in English (in the UK) or Norwegian (in Norway), we recruited participants not through snowballing but via particular networks. In the Norwegian context, a focus group with four women in their mid-40s to early 60 s was conducted in connection with a Norwegian class the women were attending. In the course of the focus group discussion, it was clear that among the most valued things about Norway was the fact that a woman can go out by herself, at any time of the day, and that this is totally accepted. The women in the group stressed that to them this was about their individual freedom, as well as about gender relations and equality. In the UK, a similar focus group was organised with five first-generation Pakistani women between 54 and 75 years old, who had lived in the UK between 24 and 41 years. Their English was very basic and an interpreter had to be involved. However, their knowledge of the current debates on citizenship and integration (the expressive field of the spirit of the time) was quite formidable, especially considering that their comprehension of English media was limited. They articulated in Panjabi that they were British citizens in all ways and also made reference to legal reasons as to why it would be impossible for them to be forced to return. Rather than basing their argument on the ties they still entertained with Pakistan and the possibility of returning in case they did not feel welcome anymore, they were not willing to consider such a possibility, as they were strongly aware of their rights as citizens, thus using the same language of integration of the debates they were aware of (the formative aspect of the spirit of the time).

These women, who had lived substantial parts of their lives in Norway and the UK, while appreciative of individual freedom and of gender equality in these societies, would generally be perceived as not integrated. Their Norwegian or English was very basic, they were all wearing traditional Pakistani clothing, and none of them was in formal employment at the time of the focus group discussions. As such, these were women, who are at the receiving end of integration policies seeking to address the imbalance in in-public life participation, where a relatively small proportion of Pakistani first-generation female migrants are active both in Norway and the UK and are seen as poorly integrated. By contrast, our findings suggest that despite their lacking participation in the labour market, and their weak language skills, these women are committed to core societal values in their societies of residence. 
This commitment to individual freedom is even more obvious when talking with members of the first wave of migration in the UK, who often felt they did not need to learn English because of how factory work was organised and sustained a myth of return for a very long time. In spite of that, they had a strong argument for the positivity of British multiculturalism. For example, 80-year-old Rehmat, in Britain since 1957, argued that one of the reasons why he liked living in Britain was that he could practice Islam without any restrictions. Of course, the same would apply to Pakistan, but it is important to note that freedom of cult was considered by Rehmat as a necessary condition for his settlement, and he believed that multicultural policies had shaped a country that facilitated his religious practice, based on the idea of individual freedom for all. He was proud when remembering how there was no mosque to attend when he first arrived, and how many mosques there are now, and the fact that children attending schools can do so without jeopardising their customs.

The implication of the political climate on social cohesion and integration, as experienced by our research participants, leads to sustaining the discursive possibility of return, based on the high degree of ambivalence with regard to, on the one hand, highly valuing the principles of individual freedom and gender equality in societies such as the British and the Norwegian, but simultaneously experiencing double standards among other through institutionalised expressions of xenophobia. In the UK, the research showed a high degree of awareness of discriminatory practices, although mainly not directly experienced. This was particularly true with younger British Pakistanis, a finding which is consistent with research that sees secondgeneration migrants more alert to discrimination because they are more aware of their rights and therefore have higher expectations about how they should be treated as equal citizens (Heath 2013) - they are an expression of a certain way of thinking, but this way of thinking becomes formative of their decisions whether to engage or not in an alleged inclusive society they often feel is still not yet so. This was less pronounced in the Norwegian case, although a consciousness about the implication of being a 'visible minority' was very clear. Overall, there seems to be a great disparity with regard to the ways in which migrants and descendants think about their own role and place in Norway and the UK and public perceptions of social cohesion and integration. While for some migrants, this mismatch can lead to sustaining the discursive possibility of return, for others, the mismatch remains an implicit and invisible reminder that parts of the society are not accepting you.

\section{Political Climate III: Terrorist Attacks}

Critical events (Das 1995) are often triggers of reflection. In our encounters with research participants, the terrorist attacks in London (7/7 bombings) in 2005 and the Utøya shooting and terrorist attack in Oslo (22 July) in 2011 were in different ways such critical events. Debates about the place of populations such as those of Pakistani descent in the British and Norwegian societies followed. While the two terrorist attacks were different in nature, questions about Islamist terrorism and Islamophobia and increasing rates of anti-immigrant rhetoric in their wake were shared. These critical events clearly affected the political climate in each context, in turn with implications (potential or actual) for migrants' and descendants' return imaginaries. 
In the UK, Muslims have been at the core of discussions on home-grown terrorism since 2001. Since the 7/7 bombings, more attention has been focused on young men of Pakistani heritage, as three of four of the London bombers were second-generation Pakistanis. The feeling of insecurity and introjection of an imposed identity as 'fifth column' (see Modood 2004) so prevalent in interviews about return collected between 2002 and 2004 (see Bolognani 2007) have progressively been wiped away by a number of factors including the diversity push implemented through public investment and the popularisation of a discourse on belonging that stresses the 'British' in any hyphenated identity. In spite of numerous grievances about Islamophobia (Werbner 2005) and racial discrimination (Webster 2003), a recent survey has found that Pakistanis in the UK are the most likely minority to self-define as 'British' (Moosavi 2012). Although one's selfascription in this sense may not be in contradiction with return imaginaries, this positioning may be interpreted as a sign of a refractory attitude to marginalisation of one's group in public discourse - in this case, these discourses can become formative of a new enhanced British identity.

In Norway, the Utøya shooting and terrorist attacks in Oslo on 22 July 2011 were discussed explicitly by some research participants, who found the attacks and the immediate aftermath terrifying. In an interview, Mahmona ${ }^{4}$ described what several others also referred to, reactions to the terrorist attack and shootings as the story was unfolding in the media:

On 22nd of July, before we knew that he did it, the first thing I started thinking was "is now the time to move back to Pakistan, to move from Norway?" With regard to our safety... people were very prejudiced, and I got really scared myself. I thought if it's a Muslim or a foreigner, I'm too scared to take the metro, to interact with others. So then, I think that is the only time my parents have thought about return to Pakistan, for a couple of hours. And then they just stopped thinking about it. And it was because of prejudice and for our safety...that's why they were thinking about this. They thought they didn't have a choice. (Young female medical doctor, grew up in Norway)

Mahmona herself was coming back from work at the emergency room, and was getting the bus home, when she heard the news of the terrorist attack via text messages. She was wearing jeans and a jacket, and she noticed another woman waiting for the bus, who was looking suspiciously at her. She remembered reflecting on why that might be the case and whether she was imagining it. She then spoke to the woman and said it was terrible about the attacks and really frightening that something like this could happen in Oslo. The woman immediately responded in a friendly way. When Mahmona arrived home to her parents' house, she encountered their panic and sudden plans for going to Pakistan, to escape Norway. The sense was that if the terrorist attack had been perpetrated by Islamist extremists, it would not have been possible to be a Muslim in Norway any longer. In the first hours after the terrorist attacks, and before the terrorist was connected to the Utøya shootings and identified, substantial proportions of Norwegian and international media did speculate that the terrorist attack was likely to be of the hands of Islamists.

\footnotetext{
${ }^{4}$ Names are pseudonyms
} 
When it turned out that the terrorist was a white male anti-immigration and anti-Muslim extremist and that descendants of migrants, including Muslims, were among victims of the shooting at the Utøya youth camp, the framing of the discussion changed. However, in interviews during the year after the event, most research participants did not seem to believe the terrorist act had changed much with regard to anti-immigration rhetoric in the public debate in Norway. Furthermore, the lack of dealing with the anti-immigrant and anti-Muslim ideology which the perpetrator represented is an important factor shaping the political climate in Norway, not because there is a great rise in right-wing extremism associated with anti-immigration rhetoric but because there is a silence and a lack of confrontation with populist anti-immigration and anti-Muslim ideology.

The implication of the political climate in the immediate aftermath of terrorist attacks, as well as in the periods following, is both something our research participants mentioned explicitly (reflective of the historical moment) and something which is implicitly affecting the nature of the political climate on immigration as well as their own integration overall (the formative effect). These developments taken together-the terrorist acts themselves, the mediatised discussions of them and the effects of these on the political climate-lead to a re-newed attention to return imaginaries. Terrorist attacks, as critical events, affect the political climate and through this also affect the space for building and consolidating belonging in culturally and religiously diverse societies, where it - based on our data - may seem that such space is currently somewhat more available in the UK, than in Norway, although both contexts and political climates are under constant change.

\section{Conclusion: Changing Return Imaginaries}

Our hypothesis was that political climates in immigration countries affect migrants' return imaginaries. We have examined how Pakistani migrants and descendants relate to immigration control, social cohesion and integration agendas, and terrorism debates as dimensions of the political climate that affect their sense of belonging in the UK and in Norway. Further, we hypothesise that migrants' and descendants' sense of belonging is strongly connected with ideas connected with ancestral roots (including notions of return) and formative ideas of a socio-political nature in which they are socialised in the country of residence. However, in the context of Pakistani populations in the UK and Norway, return ideas are not necessarily connected with actual mobility. However, we argue, the existence of a discursive possibility of return is significant for frames of belonging and inclusion in societies like the British and Norwegian.

Overall, we find that particular traits of the political climate both in the UK and in Norway sustain return imaginaries, at some level, but that critical events-whether in individuals' lives or in society - are more often precursors for such imaginary, discursive possibilities being acted upon in the form of mobility, such as in the discussed case of Iqbal's transnational marriage and the Home Office letter. Here, the existence of return imaginaries, the discursive possibility of return, was paradoxically strengthened by the Home Office letter prompting Iqbal to 'move back', as he experienced this as a signal that his contributions to British society were not being valued and his belonging in the UK was thoroughly questioned in light of his Pakistani heritage. While he had 
until then happily been a British citizen of Pakistani origin, this was turned upside down by the institutional treatment he experienced, which left him feeling alienated, for the first time in his life. One-off events, such as the letter, in combination with the wider political climate and the formative ideas it generates, have an effect on migrants' and descendants' belonging and on the ways in which a discursive possibility of return may be ignited or re-ignited at different points in time.

As we have argued in this article, return imaginaries are primarily related to questions about belonging and can therefore be a useful tool for further understanding and unpacking integration processes. In particular, the idea of a discursive possibility of return stresses that dual ties should be, and to a large extent are, socially permitted in European societies. Drawing on the knowledge that transnationalism and integration are not a zero-sum game, it is therefore not a priori negative that return imaginaries exist and change over time; it does not mean that migrants and descendants are not committed to their European societies of settlement. Our findings point quite to the contrary. Yet, it is striking that the option of return, as an idea-a return imaginaryeven at the most abstract level, seems to be strengthened by particular traits of the political climate, in ways which are alienating and which do not contribute to goals of social cohesion in the UK and in Norway. Drawing on analysis of migrants' own perceptions and experiences of political climate through the prism of 'return imaginaries', we find that there are feedback mechanisms operating in relation to political climates in European societies, which merit further academic scrutiny, as well as political sensitivities, underscoring the enduring relevance of Stuart Hall's (1996) analysis of culture, ideology and representations as formative, not only expressive, of contemporary politics.

Acknowledgments This research was funded by the Research Council of Norway under the Welfare, Labour and Migration programme (VAM) and carried out as part of the research project Possibilities and Realities of Return Migration (2011-2015). We are grateful for comments provided by colleagues on the Possibilities and Realities of Return Migration project, from Mikkel Rytter, and anonymous reviewers, which have helped develop our argument.

Open Access This article is distributed under the terms of the Creative Commons Attribution 4.0 International License (http://creativecommons.org/licenses/by/4.0/), which permits unrestricted use, distribution, and reproduction in any medium, provided you give appropriate credit to the original author(s) and the source, provide a link to the Creative Commons license, and indicate if changes were made.

\section{References}

Ahmad, A. N. (2008). The labour market consequences of human smuggling: 'illegal' employment in London's migrant economy. Journal of Ethnic and Migration Studies, 34, 853-74.

Blinder, S., (2013). Imagined immigration: the impact of different meanings of 'immigrants' in public opinion and policy debates in Britain. Political Studies.

Blinder, S., \& Jeannet, A. M., (2014). Numbers and waves, the illegal and the skilled: the effects of media portrayals of immigrants on public opinion in Britain. Available at SSRN 2476123.

Bolognani, M. (2007). The myth of return: dismissal, survival or revival? A Bradford example of transnationalism as a political instrument. Journal of Ethnic and Migration Studies, 33, 59-76.

Bolognani, M. (2014). Visits to the country of origin: how second-generation British Pakistanis shape transnational identity and maintain power asymmetries. Global Networks, 14, 103-20.

Bolognani, M. (2015). 'From myth of return to return fantasy: a psychosocial interpretation of migration imaginaries'. In Identities ahead-of-print 1-17. 
Bolognani, M., \& Statham, P. (2013). The changing public face of Muslim associations in Britain: coming together for common 'social' goals? Ethnicities, 13, 229-49.

Carling, J. (2002). Migration in the age of involuntary immobility: theoretical reflections and Cape Verdean experiences. Journal of Ethnic and Migration Studies, 28(1), 5-42.

Carling, J. (2008). The human dynamics of migrant transnationalism. Ethnic and Racial Studies, 31, $1452-77$.

Carling, J. (2015). The myth of return, in Stone, J., Dennis, R.M, Rizova, P.S, Smith, A.D., and Hou, X., (eds.) The Wiley-Blackwell Encyclopedia of Race, Ethnicity and Nationalism.

Carling, J., \& Pettersen, S. V. (2014). Return migration intentions in the integration-transnationalism matrix. International Migration, 52(6), 13-30.

Das, V. (1995). Critical events. New York: Oxford University Press.

Erdal, M. B. (2012). 'A place to stay in Pakistan': why migrants build houses in their country of origin. Population, Space and Place, 18, 629-41.

Erdal, M. B. (2013). Migrant transnationalism and multi-layered integration: Norwegian-Pakistani migrants' own reflections. Journal of Ethnic and Migration Studies, 39, 983-99.

Erdal, M. B. (2014). 'This is my home' Pakistani and Polish migrants' return considerations as articulations about 'home'. Comparative Migration Studies, 2(3), 361-384.

Erdal, M. B., \& Ezzati, R. (2015). 'Where are you from' or 'when did you come'? Temporal dimensions in migrants' reflections about settlement and return. Ethnic and Racial Studies, 38(7), 1202-1217.

Erdal, M. B., \& Oeppen, C. (2013). Migrant balancing acts: ways of understanding the interactions between integration and transnationalism. Journal of Ethnic and Migration Studies, 39, 867-84.

Erdal, M. B., Amjad, A., Bodla, Q., \& Rubab, A. (2015). Going back to Pakistan for education? The interplay of return mobilities, education and transnational living. Population, Space and Place. doi:10.1002/psp. 1966.

Fangen, K. (2007a). Breaking up the different constituting parts of ethnicity: the case of young Somalis in Norway. Acta Sociologica, 50, 401-14.

Fangen, K. (2007b). Citizenship among young adult Somalis in Norway. Young, 15, 413-34.

Fangen, K., \& Vaage, M. N. (2014). FrP-politikeres innvandringsretorikk i posisjon og opposisjon. Agora : Journal for metafysisk spekulasjon.

Figenschou, T. U., \& Beyer, A. (2014a). Elitene, minoritetene og mediene: Definisjonsmakt i norsk innvandringsdebatt. Tidsskrift for samfunnsforskning, 55(1), 24-51.

Figenschou, T. U., \& Beyer, A. (2014b). The limits of the debate: how the Oslo terror shook the Norwegian immigration debate. International Journal of Press/Politics, 19(4), 430-452.

Ford, R., Jennings, W., \& Somerville, W., (2015). Public opinion, responsiveness and constraint: Britain's three immigration policy regimes. Journal of Ethnic and Migration Studies, (ahead-of-print), 1-21.

Hall, S. (1996). New ethnicities. In D. Morley \& K.-H. Chen (Eds.), Stuart Hall: Critical Dialogues in Cultural Studies (pp. 442-51). New York: Routledge.

Hannam, K., Sheller, M., \& Urry, J. (2006). Editorial: mobilities, immobilities and moorings. Mobilities, 1, 1-22.

Heath A. (2013). Patterns of generational change: convergent, reactive or emergent? Ethnic and Racial Studies

Hjälm, A. (2014). The 'stayers': dynamics of lifelong sedentary behaviour in an urban context. Population, Space and Place, 20, 569-80.

King, R., \& Christou, A. (2014). Second-generation "return" to Greece: new dynamics of transnationalism and integration. International Migration, 52, 85-99.

Martin, K., \& Smith, K. (2014). UKIP and the rise of populist politics. Anthropology Today, 30, 1-3.

McKay, F. H., Thomas, S. L., \& Blood, R. W. (2011). 'Any one of these boat people could be a terrorist for all we know!' Media representations and public perceptions of 'boat people' arrivals in Australia. Journalism, 12(5), 607-626.

Modood, T. (2004). Multiculturalism, Muslims and the British state. In S. Sutcliffe (Ed.), Religion: Empirical Studies (p. 245). Farnham: Ashgate.

Moosavi, L. (2012). Muslims are well-integrated in Britain-but no one seems to believe it. In The Guardian. comment is free.

Pardos-Prado S, Lancee B, Sagarzazu I. (2013). Immigration and electoral change in mainstream political space. Political Behaviour

Pérez, E. O. (2015). Xenophobic rhetoric and its political effects on immigrants and their co-ethnics. American Journal of Political Science, 59, 549-564.

Rytter, M. (2011). Money or education? Improvement strategies among Pakistani families in Denmark. Journal of Ethnic and Migration Studies, 37, 197-215.

Spalek, B. (2011). New terrorism' and crime prevention initiatives involving Muslim young people in the UK: research and policy contexts. Religion, State and Society, 39, 191-207.

Thorsen, D. (2010). The place of migration in girls' imagination. Journal of Comparative Family Studies, 41. 
Vassenden, A. (2010). Untangling the different components of Norwegianness. Nations and Nationalism, 16, $734-52$.

Webster, C. (2003). Race, space and fear: imagined geographies of racism, crime, violence and disorder in Northern England. Capital and Class, 27, 95-122.

Werbner, P. (2005). Islamophobia: incitement to religious hatred-legislating for a new fear? Anthropology Today, 21, 5-9.

Worley, C. (2005). 'It's not about race. It's about the community': new labour and 'community cohesion. Critical Social Policy, 25, 483-96.

Yılmaz, F. (2012). Right-wing hegemony and immigration: how the populist far-right achieved hegemony through the immigration debate in Europe. Current Sociology, 60, 368-81. 